\title{
Long-Term Monitoring of Noxious Bacteria for Construction of Assurance Management System of Water Resources in Natural Status of the Republic of Korea
}

\author{
Young Yil Bahk ${ }^{1}$, Hyun Sook Kim² ${ }^{2}$, Ok-Jae Rhee ${ }^{3}$, Kyung-A You ${ }^{4}$, Kyung Seon Bae ${ }^{4}$, Woojoo Lee', \\ Tong-Soo Kim ${ }^{6 *}$, and Sang-Seob Lee ${ }^{2 *}$ \\ 'Department of Biotechnology, College of Biomedical and Health Science, Konkuk University, Chungju 27478, \\ Republic of Korea \\ ${ }^{2}$ Department of Life Science, Graduate School, Kyonggi University, Suwon 16227, Republic of Korea \\ ${ }^{3}$ DK EcoV Environmental Microbiology Lab., Cheonan 31075, Republic of Korea \\ ${ }^{4}$ Environmental Infrastructure Research Department, Water Supply and Sewerage Research Division, National \\ Institute of Environmental Research, Incheon 22689, Republic of Korea \\ ${ }^{5}$ Department of Public Health Science, Graduate School of Public Health, Seoul National University, Seoul 08826, \\ Republic of Korea \\ ${ }^{6}$ Department of Parasitology and Tropical Medicine, School of Medicine, Inha University, Incheon 22212, Republic \\ of Korea
}

Climate change is expected to affect not only availability and quality of water, the valuable resource of human life on Earth, but also ultimately public health issue. A six-year monitoring (total 20 times) of Escherichia coli 0157, Salmonella enterica, Legionella pneumophila, Shigella sonnei, Campylobacter jejuni, and Vibrio cholerae was conducted at five raw water sampling sites including two lakes, Hyundo region (Geum River) and two locations near Water Intake Plants of Han River (Guui region) and Nakdong River (Moolgeum region). A total 100 samples of $40 \mathrm{~L}$ water were tested. Most of the targeted bacteria were found in $77 \%$ of the samples and at least one of the target bacteria was detected (65\%). Among all the detected bacteria, E. coli 0157 were the most prevalent with a detection frequency of $22 \%$, while $S$. sonnei was the least prevalent with a detection frequency of $2 \%$. Nearly all the bacteria (except for S. sonnei) were present in samples from Lake Soyang, Lake Juam, and the Moolgeum region in Nakdong River, while $C$. jejuni was detected in those from the Guui region in Han River. During the six-year sampling period, individual targeted noxious bacteria in water samples exhibited seasonal patterns in their occurrence that were different from the indicator bacteria levels in the water samples. The fact that they were detected in the five Korea's representative water environments make it necessary to establish the chemical and biological

Received: May 1, 2020 Accepted: July 28, 2020

First published online: July 31,2020

${ }^{*}$ Corresponding authors S-S.Lee

Phone: +82-31-249-9642

E-mail: sslee@kyonggi.ac.kr

T.S.Kim

Phone: +82-32-860-9812

Fax: +82-32-885-8302

E-mail: tongsookim@inha.ac.k

pISSN 1017-7825

eISSN 1738-8872

Copyright(C) 2020 by

The Korean Society for

Microbiology and

Biotechnology analysis for noxious bacteria and sophisticated management systems in response to climate change.

Keywords: Noxious bacteria, catchment-scale investigation, water resource, climate change

\section{Introduction}

Life on Earth are greatly affected by the dynamics of climate system, especially the Earth's surface climate. In particular, infectious pathogens are emerging as a source of issue as many aspects of public health accompanying the climate change are widely recognized $[1,2]$. The term pathogen covers a wide range of disease agents, such as virus, bacteria, parasitic germs, and fungi that can affect human beings either directly or indirectly through influencing the habitat, environment, or by competing with other pathogens. Climate change is a global phenomenon and is expected to accelerate in the future, especially in situations where the extent of climate change on Korean peninsula is relatively large (e.g., temperature rise, rainfall change, etc.) [3]. The annual mean temperature has been increasing at a rate of $0.52^{\circ} \mathrm{C}$ per decade and is significantly larger over urbanized areas [4], and it is anticipated that the incidence and geographic distribution of vector-borne diseases will change as a result [5].

Shigella is a genus of gram-negative pathogenic enterobacteria and a pathogenic variant of Eschericha coli comprising four groups, Shigella boydii, S. dysenteriae, S. sonnei, and S. flexneri [6]. Shigella species are water- 
borne and food-borne agents of bacillary gastrointestinal dysentery or shigellosis responsible for an estimated 80165 million cases worldwide and account for a primary cause of childhood morbidity and mortality [7]. S. sonnei and S. flexneri result in most Shigellosis cases, with S. sonnei causing over $80 \%$ of all shigellosis infections and is increasingly found in developing countries [8]. In developing countries, especially where exist various public health problem caused by poor hygiene standards, a safe supply of drinking water influences the risk of public health.

Enterohemorrhagic E. coli $\mathrm{O} 157$ is a subtype of shiga toxin-producing E. coli and a primary food-borne pathogen causing the severe diseases in human such as hemolytic uremic syndrome, thrombotic thrombocytopenic purpura, and hemorrhagic colitis worldwide, although elderly and children are more expugnable [9].

Salmonellae are facultative anaerobic gram-negative bacteria belonging to the family Enterobacteriaceae and are a medically pivotal pathogen; two main species are Salmonella bongorin and S. enterica [10]. S. enterica has six subspecies that are composed of over 1500 subtypes some of which have profound medical significance [11]. Salmonella is an international food-borne intravacuolar pathogen causing a huge number of deaths and has a substantial cost burden. S. enterica subsp. enterica is responsible of more than $99 \%$ of human salmonellosis cases [12].

Legionella pneumophila, which causes community-acquired pneumonia that requires hospitalization, is an opportunistic pathogen that is omnipresent in aquatic environments in which it replicates in free-living amoebae $[13,14]$. L. pneumophila pneumonia is strongly associated with high morbidity. Moreover, legionellosis is consistently reported as one of the top three most identified respiratory pathogens in community-acquired pneumonia, along with the hospital-acquired pneumonia [15].

Campylobacterota, formerly identified as Epsilon proteobacteria, are a whole bunch of gram-negative motile bacteria found in manifold ecological habitats [16]. Campylobacterota are pivotal clinical pathogens in human; the gut of half of the human beings is mass-dwelled with the stomach ulcer-causing bacterium Helicobacter pylori, while Campylobacter jejuni is a ubiquitous gastrointestinal pathogen and one of the majorly diagnosed bacterial food-borne pathogens in human and remains among the most common causes of bacterial gastroenteritis in many areas of world [17]. Campylobacteria infection causes the development of miscarriage, septicemia, gastroenteritis, proctitis, meningitis, and many neurological diseases, the foremost of which is Guillain-Barré syndrome among other central nervous system (CNS) diseases with similar acute progresses. Large global population (1-10\% of the whole) can influence the risk of campylobacteriosis annually [18]. The non-food-borne transmission pathways for Campylobacter to human are birds and animals in which C. jejuni is part of normal flora, with the major pathway of transmission being the ingestion of contaminated food or drinking water [19].

Vibrio cholerae is a motile, aquatic curved-rod facultative gram-negative anaerobe belonging to the family of Vibrionaceae. Cholera caused by an etiological agent, V. cholerae, has been a serious epidemic secretary diarrheal disease that can quickly lead to severe dehydration and prove fatal within hours if untreated. Strains of V. cholerae inhabit both marine and freshwater ecosystems [20,21]. Despite great betterments in hygiene, water quality, and sanitation, as well as in the clinical treatment, the disease is still estimated to cause about 100,000 deaths every year.

Climate change is causing water scarcity not only through increased temperatures and prolonged drought times but also through the degradation of water resources caused by increasing levels of pathogens and other contaminants posing significant health risks [22]. Thus, there is clearly a strong need for establishing management strategies and constant monitoring the water resources based on the results of testing water for contamination from relevant sources. Herein, we report the results on long-term (six-year) surveillance of noxious bacteria (E. coli O157, S. enterica, L. pneumophila, S. sonnei, C. jejuni, and V. cholera) from August 2013 to February 2019 at various locations in Republic of Korea (Korea) to help the establishment of the management systems to maintain water quality and security.

\section{Material and Methods \\ Collection Sites}

A catchment scale investigation of the prevalence of E. coli O157, S. enterica, L. pneumophila, S. sonnei, C. jejuni, and V. cholera was carried out. Water samples were collected 20 times from August 2013 to February 2019 from five surface water sampling locations: two lakes (Lake Soyang in Gangwon province and Lake Juam in Jeollanam province), Hyundo region (near Hyundo Bridge of Geum River at Shintanjin-dong in Daejeon Metropolitan City (Daejeon)), and two water intake plants (the Guui region on Han River in Seoul Special City (Seoul) and the Moolgeum region on Nakdong River in Gimhae-si) (Table 1). These five locations were selected to reflect the environment in response to changes in the landscape according to the climate change scenario by Intergovernmental Panel on Climate Change (IPCC): the Moolgeum region of Nakdong River, which is a

Table 1. Climate characteristics and geographic indexes the sample collection sites.

\begin{tabular}{|c|c|c|c|}
\hline Collection sites & Climate classification & Geographic indexes & Characteristics \\
\hline Lake Soyang & Exceptional Subtropic Zone & $37.5654 / 127.4855$ & Lake \\
\hline The Guui region on River Han in Seoul & RCP 8.5 Subtropic Zone & $37.3305 / 127.0641$ & River \\
\hline $\begin{array}{l}\text { The Hyundo region (near Hyundo Bridge of } \\
\text { Geum River at Shintanjindong in Daejeon) }\end{array}$ & RCP 8.5 Subtropic Zone & $36.2724 / 127.2544$ & River \\
\hline Lake Juam & RCP 4.5 Subtropic Zone & $35.0340 / 127.1412$ & Lake \\
\hline The Moolgeum Region on the Nakdong River & Subtropic Zone & $35.1834 / 128.5837$ & River \\
\hline
\end{tabular}


subtropical zone; Lake Juam, which is classified as Representative Concentration Pathway (RCP) 4.5 proceeding to subtropical zone; the Guui region of Han River and the Hyundo region of Geum River, which are RCP 8.5 zones; and Lake Soyang, which is considered as non-subtropical zone in Korea.

\section{Testing of Indicator Bacteria}

Water samples were collected from each location. E. coli contamination were measured in samples using a Most Probable Number (MPN) assay. One hundred $\mathrm{ml}$ aliquots of water samples from each location were evaluated for total coliform (TC), fecal coliform (FC) and E. coli contamination and an IDEXX Colilert-18 and Quanti-Tray System (IDEXX Laboratories, USA). The collected water samples were placed immediately in a refrigerator $\left(4^{\circ} \mathrm{C}\right)$ upon collection using sterile bags and transported to private laboratory in Kyonggi University for further processing. Briefly, the process started by adding a Colilert- 18 reagent to each sample until it fully dissolved. The mixture was placed in a Quanti-Tray, which was sealed and incubated at $35^{\circ} \mathrm{C}$ and $44.5^{\circ} \mathrm{C}$ for $24 \mathrm{~h}$ each. Following incubation and positive well counts, the results were obtained using the IDEXX results table, where the number of colored and fluorescing large and small cells determined the MPN for coliform bacteria and E. coli. For each test sample, appropriate dilutions were prepared. This system is based on the MPN technique [23] and is a semiautomatic enzyme-based assay reduced to multi-wells. Control samples of commercially available sterile water were included along with the samples to evaluate cross- contamination.

\section{Quality of the Collected Water Samples}

Physiochemical parameters such as $\mathrm{pH}$, total dissolved solids, dissolved oxygen (DO), total nitrogen, ammonia, nitrate, nitrite, phosphate, and sulfate were analyzed according to the Standard Methods for the Examination of Water and Wastewater [24]. Turbidity and conductivity were measured with a HACH 1900C portable turbidity meter $(\mathrm{HACH}, \mathrm{USA})$ and a $\mathrm{HACH}$ sension 5 conductivity meter $(\mathrm{HACH})$, respectively. $p \mathrm{H}$ was measured on-site using individually calibrated portable testers. Chemical oxygen demand (COD) and ammonium content $\left(\mathrm{NH}_{3}\right.$ N) were measured according to standard method $[25,26]$.

\section{Sample Collection and Analysis}

The targeted bacteria were S. sonnei, E. coli O157, S. enterica spp., L. pneumophila, C. jejuni, and V. cholerae. Spatially distributed samples were aseptically collected at five locations using sterile containers (Table 1). Samples were simultaneously and in parallel examined for the detection of 6 noxious bacteria. One-liter aliquots from each of five consecutive sampling were filtered using $0.2 \mathrm{~mm}$ filters to collect particulates. The filters were processed and extracted DNA using GeneAll Exgene Soil DNA kits (GeneAll Biotechnology, Korea) according to the manufacturer's recommendation. The concentration of the extracted DNA was determined by measuring

Table 2. Primer set sequences used for noxious bacteria and cycling parameters in this study.

\begin{tabular}{|c|c|c|c|c|}
\hline Species & Target gene & Primer sequences & $\begin{array}{l}\text { Product } \\
\text { size }\end{array}$ & Cycling parameters \\
\hline $\begin{array}{l}\text { Shigella } \\
\text { sonnei }\end{array}$ & $\begin{array}{l}\text { Hypothetical } \\
\text { protein }\end{array}$ & $\begin{array}{l}\text { F: 5'ACGCGTTAAAGATGATGCCTGTT-3' } \\
\text { R: 5'-TGCCGCTAAAATCCTTCTGTCCT-3' }\end{array}$ & 325 bp & $\begin{array}{l}\text { Initial denaturation: } 95^{\circ} \mathrm{C}(2.5 \mathrm{~min}) \\
45 \mathrm{cycles} \text { of } 95^{\circ} \mathrm{C}(10 \mathrm{sec}), 60^{\circ} \mathrm{C}(20 \mathrm{sec}) \\
\text { Denaturation: } 95^{\circ} \mathrm{C}(10 \mathrm{sec}) \\
\text { Slope range: } 65-95^{\circ} \mathrm{C} \text { for melting curve } \\
\text { and melting peak }\end{array}$ \\
\hline E. coli $\mathrm{O} 157$ & $\begin{array}{l}\text { Hypothetical } \\
\text { protein }\end{array}$ & $\begin{array}{l}\text { F: 5-GCCGTACATGCTGCTGAGAGTC-3' } \\
\text { R: 5'-TAGCCCCATATAGCGTAAGAAT-3' }\end{array}$ & $215 b p$ & $\begin{array}{l}\text { Initial denaturation: } 95^{\circ} \mathrm{C}(2.5 \mathrm{~min}) \\
45 \mathrm{cycles} \text { of } 95^{\circ} \mathrm{C}(10 \mathrm{sec}), 59^{\circ} \mathrm{C}(20 \mathrm{sec}) \\
\text { Denaturation: } 95^{\circ} \mathrm{C}(10 \mathrm{sec}) \\
\text { Slope range: } 65-95^{\circ} \mathrm{C} \text { for melting curve } \\
\text { and melting peak }\end{array}$ \\
\hline $\begin{array}{l}\text { Salmonella } \\
\text { enterica }\end{array}$ & $\begin{array}{l}\text { Hypothetical } \\
\text { protein }\end{array}$ & $\begin{array}{l}\text { F: 5'-CGCGTCGCTTCGTTCTGTATCAT-3' } \\
\text { R: 5'-GCGCTGCCACTCTCGGTTTCTTAT-3' }\end{array}$ & 353 bp & $\begin{array}{l}\text { Initial denaturation: } 95^{\circ} \mathrm{C}(2.5 \mathrm{~min}) \\
45 \text { cycles of } 95^{\circ} \mathrm{C}(10 \mathrm{sec}), 50^{\circ} \mathrm{C}(20 \mathrm{sec}) \\
\text { Denaturation: } 95^{\circ} \mathrm{C}(10 \mathrm{sec}) \\
\text { Slope range: } 65-95^{\circ} \mathrm{C} \text { for melting curve } \\
\text { and melting peak }\end{array}$ \\
\hline $\begin{array}{l}\text { Legionella } \\
\text { pneumophila }\end{array}$ & $\begin{array}{l}\text { Hypothetical } \\
\text { protein }\end{array}$ & $\begin{array}{l}\text { F: 5'-ACACGTTGAAGAGGAGTTAG-3' } \\
\text { R: 5'-ACAAGCTCTACTTCAATGCC-3' }\end{array}$ & 264 bp & $\begin{array}{l}\text { Initial denaturation: } 95^{\circ} \mathrm{C}(2.5 \mathrm{~min}) \\
45 \text { cycles of } 95^{\circ} \mathrm{C}(10 \mathrm{sec}), 59^{\circ} \mathrm{C}(20 \mathrm{sec}) \\
\text { Denaturation: } 95^{\circ} \mathrm{C}(10 \mathrm{sec}) \\
\text { Slope range: } 65-95^{\circ} \mathrm{C} \text { for melting curve } \\
\text { and melting peak }\end{array}$ \\
\hline $\begin{array}{l}\text { Vibrio } \\
\text { cholerae }\end{array}$ & $\begin{array}{l}\text { Hypothetical } \\
\text { protein }\end{array}$ & $\begin{array}{l}\text { F: 5'-CCGTTGAGGCGAGTTTGGTGAGA-3' } \\
\text { R: 5'-GTGCGCGGGTGGAAACTTATGAT-3' }\end{array}$ & 195 bp & $\begin{array}{l}\text { Initial denaturation: } 95^{\circ} \mathrm{C}(2.5 \mathrm{~min}) \\
45 \text { cycles of } 95^{\circ} \mathrm{C}(10 \mathrm{sec}), 52^{\circ} \mathrm{C}(20 \mathrm{sec}) \\
\text { Denaturation: } 95^{\circ} \mathrm{C}(10 \mathrm{sec}) \\
\text { Slope range: } 65-95^{\circ} \mathrm{C} \text { for melting curve } \\
\text { and melting peak }\end{array}$ \\
\hline $\begin{array}{l}\text { Campylobacter } \\
\text { jejuni }\end{array}$ & $\begin{array}{l}\text { Hypothetical } \\
\text { protein }\end{array}$ & $\begin{array}{l}\text { F: 5'-AAAAAGAGATTTATATTAACAAAA-3' } \\
\text { R: 5'-GCTTAATTGTATAGTTTATATTATC-3' }\end{array}$ & 177 bp & $\begin{array}{l}\text { Initial denaturation: } 95^{\circ} \mathrm{C}(2.5 \mathrm{~min}) \\
45 \text { cycles of } 95^{\circ} \mathrm{C}(10 \mathrm{sec}), 55^{\circ} \mathrm{C}(20 \mathrm{sec}) \\
\text { Denaturation: } 95^{\circ} \mathrm{C}(10 \mathrm{sec}) \\
\text { Slope range: } 65-95^{\circ} \mathrm{C} \text { for melting curve } \\
\text { and melting peak }\end{array}$ \\
\hline
\end{tabular}


ultraviolet absorbance at $260 \mathrm{~nm}$ using a spectrophotometer (NanoDrop ND-1000, Thermo Fisher Scientific, USA), after which the samples were stored at $-70^{\circ} \mathrm{C}$ before use.

Real-time PCR analysis was conducted with $10 \mathrm{ul}$ of SYBR green master mix (Thermo Fisher Scientific) and 10 pM specific primer sets in a reaction volume of 20 ul using CFX96 Real-time PCR system (Bio-Rad Laboratories, USA). The primer set sequences and reaction conditions for each targeted noxious bacterium and the amplified target sizes represent in Table 2. The specificity of the primers was confirmed using a BLAST search in GenBank database from NCBI. For each bacterium tested in this monitoring, the BLASTn searches yield no solid match to any of the other identified bacterium reference sequences. Specificity tests were performed using conventional PCR techniques for each species or subspecies primer set against DNA samples from various bacterium strains [27]. Matches between the cyclic quantification $(\mathrm{Cq})$ value and each of noxious bacteria detection was verified, and positive estimation was determined for a single peak using the Cq value. The positive samples were analyzed and confirmed by sequencing the 16s rDNA fragments by Macrogen Inc. (Korea). Analysis of the derived nucleotide sequences was performed for matching genotypes using the NCBI-BLAST service to target the noxious bacteria.

\section{Results}

\section{Physicochemical Parameters in the Water Samples}

There were slight variations in physiochemical parameters among the water sample collecting sites. The water temperature at the Guui region and Lake Juam tended to increase slightly, while no definite trend was observed for precipitation (Data not shown). The other collection sites did not show a definite tendency in the parameters of precipitation or water temperature. Table 3 summarizes the physiochemical parameters of water samples from the five sample collecting sites during the periods from August 2013 to February 2019. All the parameters other than precipitation and water temperature fluctuated continuously through the year. The $p \mathrm{H}$ values are in the range of 6.5 to 8.5 (in a descending order: Guui region > Moolgeum region $>$ Hyundo region > Lake Soyang > Lake Juam), which according to the World Health Organization (WHO) guidelines for drinking water [28], the $p \mathrm{H}$ values at the surface fall within the normal limit. Most of the monitoring locations had a sufficient DO level (more than 7 $\mathrm{mg} / \mathrm{l}$ ), although one was borderline (Lake Juam). The conductivity values of the collected water samples were ranged from 70 to $350 \mathrm{mS} / \mathrm{cm}$ on average, which are well within the unpolluted freshwater range of 10 to $1,000 \mathrm{mS} /$ $\mathrm{cm}$. The average amount of total nitrogen in the water samples from the collection sites was $1.898 \pm 0.850 \mathrm{mg} / \mathrm{l}$, while ammoniacal nitrogen $\left(\mathrm{NH}_{3}\right.$ or $\left.\mathrm{NH}_{4}^{+}\right)$did not consistently exceed $0.3 \mathrm{mg} / \mathrm{l}$. The acceptable amount of nitrates in drinking water is up to around $44 \mathrm{mg} / \mathrm{l}$ [29], so the samples from the locations were well within this (0.4$2.1 \mathrm{mg} / \mathrm{l})$. The phosphate level in the samples was $0.025 \pm 0.021 \mathrm{mg} / \mathrm{l}$, which is well within the WHO guideline of 1 $\mathrm{mg} / \mathrm{l}$. In general, the Moolgeum region on Nakdong River had the highest values for BOD, COD, conductivity, total nitrogen, total phosphorus, and phosphate, while the Guui region on Han River in Seoul had highest values for $p \mathrm{H}, \mathrm{DO}$, ammonia, and nitrate.

\section{Indicator Bacteria and Water-Quality Monitoring Stations}

The monitoring points in this study were selected for the water quality measurements due to the needs for longterm monitoring and management of Korean rivers and lakes and the links between the nearby water quality measuring network points according to the prediction scenario for climate change: Lake Soyang in the exceptional subtropical zone and the Guui region on the Han River in Seoul, Hyundo region (near Hyundo Bridge of Geum River at Shintanjin-dong in Daejeon), Lake Juam, and the Moolgeum region on Nakdong River in the subtropical zone.

In practice, it is impossible to enumerate all pathogens in water-source because of the absence of specific

Table 3. Physicochemical characteristics of the water samples of the five collected sites in this study.

\begin{tabular}{|c|c|c|c|c|c|c|c|c|c|c|c|}
\hline $\begin{array}{l}\text { Parameter } \\
\text { Sites }\end{array}$ & $\begin{array}{c}\text { Temp. } \\
\left({ }^{\circ} \mathrm{C}\right)\end{array}$ & $\mathrm{pH}$ & $\begin{array}{c}\text { Dissolved } \\
\text { oxygen } \\
(\mathrm{mg} / \mathrm{l})\end{array}$ & $\begin{array}{l}\text { BOD } \\
(\mathrm{mg} / \mathrm{l})\end{array}$ & $\begin{array}{c}\mathrm{COD} \\
(\mathrm{mg} / \mathrm{l})\end{array}$ & $\begin{array}{c}\text { Conductivity } \\
(\mathrm{mS} / \mathrm{cm} \text { at } \\
\left.20^{\circ} \mathrm{C}\right)\end{array}$ & $\begin{array}{c}\text { Total } \\
\text { nitrogen } \\
(\mathrm{mg} / \mathrm{l})\end{array}$ & $\underset{(\mathrm{mg} / \mathrm{l})}{\text { Ammonia }}$ & $\begin{array}{c}\text { Nitrate } \\
(\mathrm{mg} / \mathrm{l})\end{array}$ & $\begin{array}{c}\text { Total } \\
\text { phosphorus } \\
(\mathrm{mg} / \mathrm{l})\end{array}$ & $\begin{array}{c}\text { Phosphate } \\
(\mathrm{mg} / \mathrm{l})\end{array}$ \\
\hline $\begin{array}{l}\text { The Guui } \\
\text { region on the } \\
\text { Han River in } \\
\text { Seoul }\end{array}$ & $\begin{array}{c}12.71 \\
\pm 9.11\end{array}$ & $\begin{array}{l}8.125 \\
\pm 0.17\end{array}$ & $\begin{array}{r}12.24 \\
\pm 1.89\end{array}$ & $\begin{array}{l}1.515 \\
\pm 0.51\end{array}$ & $\begin{array}{l}4.115 \\
\pm 0.61\end{array}$ & $\begin{array}{c}209.3 \\
\pm 47.96\end{array}$ & $\begin{array}{l}2.684 \\
\pm 0.47\end{array}$ & $\begin{array}{c}0.097 \\
\pm 0.091\end{array}$ & $\begin{array}{l}2.028 \\
\pm 0.33\end{array}$ & $\begin{array}{c}0.038 \\
\pm 0.019\end{array}$ & $\begin{array}{c}0.0065 \\
\pm 0.008\end{array}$ \\
\hline $\begin{array}{l}\text { The Moolgeum } \\
\text { region on the } \\
\text { Kakdong River }\end{array}$ & $\begin{array}{l}15.06 \\
\pm 9.50\end{array}$ & $\begin{array}{l}8.075 \\
\pm 0.37\end{array}$ & $\begin{array}{l}10.925 \\
\pm 2.45\end{array}$ & $\begin{array}{l}1.955 \\
\pm 0.52\end{array}$ & $\begin{array}{l}6.265 \\
\pm 1.22\end{array}$ & $\begin{array}{c}336.25 \\
\pm 104.24\end{array}$ & $\begin{array}{l}2.742 \\
\pm 0.57\end{array}$ & $\begin{array}{c}0.086 \\
\pm 0.035\end{array}$ & $\begin{array}{l}1.959 \\
\pm 0.60\end{array}$ & $\begin{array}{c}0.047 \\
\pm 0.027\end{array}$ & $\begin{array}{r}0.0112 \\
\pm 0.013\end{array}$ \\
\hline $\begin{array}{l}\text { The Hyundo } \\
\text { region (near } \\
\text { Hyundo Bridge } \\
\text { of Geum River } \\
\text { in Daejeon) }\end{array}$ & $\begin{array}{r}13.26 \\
\pm 6.85\end{array}$ & $\begin{array}{l}7.905 \\
\pm 0.23\end{array}$ & $\begin{array}{l}10.335 \\
\pm 2.50\end{array}$ & $\begin{array}{c}0.73 \\
\pm 0.25\end{array}$ & $\begin{array}{l}3.875 \\
\pm 0.61\end{array}$ & $\begin{array}{r}167.35 \\
\pm 26.31\end{array}$ & $\begin{array}{r}1.479 \\
\pm 0.25\end{array}$ & $\begin{array}{c}0.106 \\
\pm 0.273\end{array}$ & $\begin{array}{l}1.088 \\
\pm 0.34\end{array}$ & $\begin{array}{l}0.015 \\
\pm 0.00\end{array}$ & $\begin{array}{r}0.0032 \\
\pm 0.005\end{array}$ \\
\hline Lake Soyang & $\begin{array}{c}9.45 \\
\pm 4.70\end{array}$ & $\begin{array}{c}7.33 \\
\pm 0.35\end{array}$ & $\begin{array}{l}8.395 \\
\pm 1.65\end{array}$ & $\begin{array}{c}1.18 \\
\pm 0.26\end{array}$ & $\begin{array}{c}2.09 \\
\pm 0.32\end{array}$ & $\begin{array}{c}76.2 \\
\pm 5.73\end{array}$ & $\begin{array}{l}1.867 \\
\pm 0.31\end{array}$ & $\begin{array}{c}0.024 \\
\pm 0.014\end{array}$ & $\begin{array}{l}1.377 \\
\pm 0.17\end{array}$ & $\begin{array}{c}0.011 \\
\pm 0.006\end{array}$ & $\begin{array}{r}0.0025 \\
\pm 0.002\end{array}$ \\
\hline Lake Juam & $\begin{array}{l}11.93 \\
\pm 5.40\end{array}$ & $\begin{array}{c}6.82 \\
\pm 0.37\end{array}$ & $\begin{array}{l}6.985 \\
\pm 3.14\end{array}$ & $\begin{array}{c}0.82 \\
\pm 0.19\end{array}$ & $\begin{array}{c}2.94 \\
\pm 0.47\end{array}$ & $\begin{array}{c}79.6 \\
\pm 8.08\end{array}$ & $\begin{array}{l}0.718 \\
\pm 0.11\end{array}$ & $\begin{array}{c}0.069 \\
\pm 0.062\end{array}$ & $\begin{array}{l}0.472 \\
\pm 0.12\end{array}$ & $\begin{array}{c}0.132 \\
\pm 0.005\end{array}$ & $\begin{array}{c}0.0033 \\
\pm 0.003\end{array}$ \\
\hline
\end{tabular}


Table 4. Total indicator bacteria (MPN/100 ml) including TC, FC, and E. coli during the monitoring period.

\begin{tabular}{|c|c|c|c|c|c|c|c|c|c|c|c|c|c|c|c|c|c|c|c|c|c|c|}
\hline $\begin{array}{c}\text { Indicator } \\
\text { bacteria }\end{array}$ & $\begin{array}{l}\text { r Collection } \\
\text { sites }\end{array}$ & $\begin{array}{l}\text { Aug, } \\
2013\end{array}$ & $\begin{array}{l}\text { Oct, } \\
2013\end{array}$ & $\begin{array}{c}\text { Dec } \\
2013\end{array}$ & $\begin{array}{l}\text { Feb, } \\
2014\end{array}$ & $\begin{array}{l}\text { Aug, } \\
2014\end{array}$ & $\begin{array}{l}\text { Oct, } \\
2014\end{array}$ & $\begin{array}{l}\text { Dec, } \\
2014\end{array}$ & $\begin{array}{l}\text { Feb, } \\
2015\end{array}$ & $\begin{array}{l}\text { Dec, } \\
2015\end{array}$ & $\begin{array}{l}\text { Feb, } \\
2016\end{array}$ & $\begin{array}{l}\text { Apr, } \\
2016\end{array}$ & $\begin{array}{l}\text { Jun, } \\
2016\end{array}$ & $\begin{array}{l}\text { Aug, } \\
2017\end{array}$ & $\begin{array}{l}\text { Oct, } \\
2017\end{array}$ & $\begin{array}{l}\text { Dec, } \\
2017\end{array}$ & $\begin{array}{l}\text { Feb, } \\
2018\end{array}$ & $\begin{array}{l}\text { Aug, } \\
2018\end{array}$ & $\begin{array}{l}\text { Oct, } \\
2018\end{array}$ & $\begin{array}{l}\text { Dec, } \\
2018\end{array}$ & $\begin{array}{l}\text { Feb, } \\
2019\end{array}$ & Average \\
\hline \multirow{5}{*}{$\begin{array}{l}\text { Total } \\
\text { Coliform } \\
\text { (TC) }\end{array}$} & $\begin{array}{l}\text { Lake } \\
\text { Soyang }\end{array}$ & 90,000 & 12,000 & 5,400 & 100 & 610 & 2,400 & 550 & 67 & 32 & 70 & 150 & 1,270 & 3,700 & 1,300 & 160 & 7 & 0 & 3,400 & 170 & 65 & $6,072.55$ \\
\hline & $\begin{array}{l}\text { Han } \\
\text { River }\end{array}$ & 190,000 & 85,000 & 5,500 & 200 & 5,200 & 1,200 & 370 & 130 & 1,700 & 1,400 & 480 & 1,100 & $\begin{array}{r}160,00 \\
0\end{array}$ & 1,700 & 2,900 & 4,400 & 14,000 & 1,200 & 610 & 300 & $23,869.5$ \\
\hline & $\begin{array}{l}\text { Geum } \\
\text { River }\end{array}$ & 63,000 & 11,000 & 5,800 & 1,000 & 1,100 & 37 & 2,000 & 140 & 290 & 1,300 & 17,000 & 2,500 & 24,000 & 22,000 & 650 & 410 & & 34,000 & 2,900 & 770 & $9,494.85$ \\
\hline & $\begin{array}{l}\text { Lake } \\
\text { Juam }\end{array}$ & 110,000 & 5,900 & 5,400 & 1,400 & 6,000 & 5,500 & 130 & 14 & 150 & 17 & 260 & 980 & 7 & 2,400 & 20 & 0 & 1,000 & 5,200 & 390 & 16 & $7,239.2$ \\
\hline & $\begin{array}{l}\text { Nakdong } \\
\text { River }\end{array}$ & 190,000 & 48,000 & 1,900 & 100 & 2,300 & 9,200 & 460 & 56 & 12 & 240 & 1,900 & 3,500 & 3,700 & 8,700 & 1,000 & 220 & 6,900 & 3,900 & 520 & 180 & $14,139$. \\
\hline \multirow{5}{*}{$\begin{array}{l}\text { Fecal } \\
\text { Coliform } \\
\text { (FC) }\end{array}$} & $\begin{array}{l}\text { Lake } \\
\text { Soyang }\end{array}$ & 1 & 1 & 0 & 0 & 1 & 5.2 & 1 & 0 & 0 & 0 & 2 & 0 & 5 & 73 & 4 & 1 & 0 & 1 & 2 & 1 & 4.91 \\
\hline & $\begin{array}{l}\text { Han } \\
\text { River }\end{array}$ & 13 & 37 & 40 & 12 & 30 & 120 & 25 & 29 & 79 & 32 & 38 & 200 & 48,000 & 290 & 96 & 820 & 650 & 54 & 30 & 11 & 2530.3 \\
\hline & $\begin{array}{l}\text { Geum } \\
\text { River }\end{array}$ & 51 & 2 & 5.1 & 119 & 0 & 6 & 0 & 3 & 3 & 670 & 31 & 290 & 2,100 & 96 & 22 & 9 & 0 & 150 & 120 & 1 & 183.905 \\
\hline & $\begin{array}{l}\text { Lake } \\
\text { Juam }\end{array}$ & 1 & 5.2 & 3.1 & 0 & 0 & 310 & 2 & 0 & 0 & 0 & 8 & 0 & 0 & 68 & 2 & 0 & 200 & 3 & 0 & 0 & 30.115 \\
\hline & $\begin{array}{l}\text { Nakdong } \\
\text { River }\end{array}$ & 4.1 & 1 & 1 & 0 & 5.2 & 310 & 6.3 & 17 & 1 & 0 & 9 & 6 & 32 & 610 & 37 & 4 & 220 & 35 & 3 & 2 & 65.18 \\
\hline \multirow[t]{5}{*}{ E. coli } & $\begin{array}{l}\text { Lake } \\
\text { Soyang }\end{array}$ & 1 & 1 & 0 & 0 & 0 & 4.1 & 1 & 0 & 0 & 0 & 0 & 1 & 0 & 0 & 0 & 0 & 0 & 0 & 0 & 0 & 0.405 \\
\hline & $\begin{array}{l}\text { Han } \\
\text { River }\end{array}$ & 8.5 & 20 & 38 & 8.6 & 30 & 73 & 6.3 & 5 & 71 & 32 & 23 & 96 & 29,000 & 100 & 28 & 820 & 20 & 33 & 23 & 9 & $1,522.22$ \\
\hline & $\begin{array}{l}\text { Geum } \\
\text { River }\end{array}$ & 0 & 1 & 5.1 & 1 & 10 & 0 & 15 & 0 & 3 & 3 & 19 & 23 & 210 & 42 & 28 & 9 & 0 & 120 & 96 & 3 & 29.405 \\
\hline & $\begin{array}{l}\text { Lake } \\
\text { Juam }\end{array}$ & 1 & 3 & 3.1 & 0 & 0 & 1 & 0 & 0 & 0 & 0 & 4.1 & 0 & 0 & 0 & 0 & 0 & 0 & 0 & 0 & 0 & 0.61 \\
\hline & $\begin{array}{l}\text { Nakdong } \\
\text { River }\end{array}$ & 2 & 1 & 1 & 0 & 4.1 & 240 & 0 & 3 & 0 & 0 & 6 & 5 & 11 & 5 & 0 & 1 & 0 & 14 & 0 & 1 & 14.705 \\
\hline
\end{tabular}

detection techniques. Thus, indicator bacteria including TC, FC and E. coli are traditionally used to indicate the presence of a pathogens, especially in wastewater as well as other intestinal pathogens [30]. The presence of TC and FC is indicative of human fecal contamination. TC, FC, and/or E. coli were detected in almost samples collected across 6 year monitoring and 23\% of the samples exceeded the regulations provided by the Pennsylvania Department of Environmental Protection (PA DEP) form TC (5,000 CFU/100 ml) at concentration ranging from 0 to $1.9 \times 10^{9} \mathrm{MPN} / 100 \mathrm{ml}$ (CFU and MPU are equivalent), which were mainly observed between August and October [31]. Concentrations of the FC in 13\% exceeded the PA DEP regulations for fecal coliforms (200 CFU/ $100 \mathrm{ml}$ ) during the investigation period [31]. Spatially, the Guui region of Han River was the highest contaminated place among the monitored sites in this study, followed by Moolgeum region of Nakdong River. During the period under investigation, the TC (average: $1.2 \times 10^{4} \mathrm{MPN} / 100 \mathrm{ml}$ ) rather than FC (average: $563 \mathrm{MPN} / 100 \mathrm{ml}$ ) or E. coli (average: $313 \mathrm{MPN} / 100 \mathrm{ml}$ ) were detected highest. The averages of three indicator bacteria in August 2017 were highest $\left(3.8 \times 10^{4}, 1.0 \times 10^{4}\right.$, and $5.8 \times 10^{3} \mathrm{MPN} / 100 \mathrm{ml}$ for TC, FC and E. coli, respectively) (Table 4). Lake Soyang and Lake Juam had lower contamination than the other sites in this study. However, it is not evident from the information on precipitation and physicochemical characteristics whether the collected indicator bacteria in the collected samples were higher in August 2017 compared to other collection periods. Overall, the distribution of the indicator bacteria was found to be the highest in August (when the water temperature was high), followed by October.

\section{Relationship between Physicochemical Parameters and Indicator Bacteria}

Physicochemical parameters are among the major factors involved in the management and mitigation of nonpoint source pollution, and the effect of fecal contamination on the quality of water is a matter of quite concern. Information gained through the regular monitoring of water quality allows estimation of the likelihood pathogens-related waterborne disease [32]. In general, indicator bacteria (TC, FC, and E. coli) tended to decrease over time except in 2013 (Table 4). TC levels were higher in August and October of the year and remained at a certain level depending on the time of collection. However, TC levels in Lake Soyang and Lake Juam were the highest in October when the water temperature was low. The detection rates of FC and E. coli were stable throughout the monitoring periods. Finally, it is evident that the distribution of indicator bacteria was related to changes in turbidity due to water temperature and precipitation.

\section{Detection of Noxious Bacteria in Monitoring Sites}

Most of the targeted bacteria were found in $77 \%$ of the samples and at least one of the target bacteria was detected (65\%) (Fig. 1, Table 5). Among all the detected bacteria, E. coli O157 were the most prevalent with a detection frequency of $22 \%(22 / 100)$, while $S$. sonnei was the least prevalent with a detection frequency of $2 \%$ ( $2 /$ 100 samples). Nearly all of the bacteria (except for S. sonnei) were present in samples from Lake Soyang, Lake Juam, and Nakdong River (Fig. 2), while C. jejuni was detected in those from Han River. During the six-year 


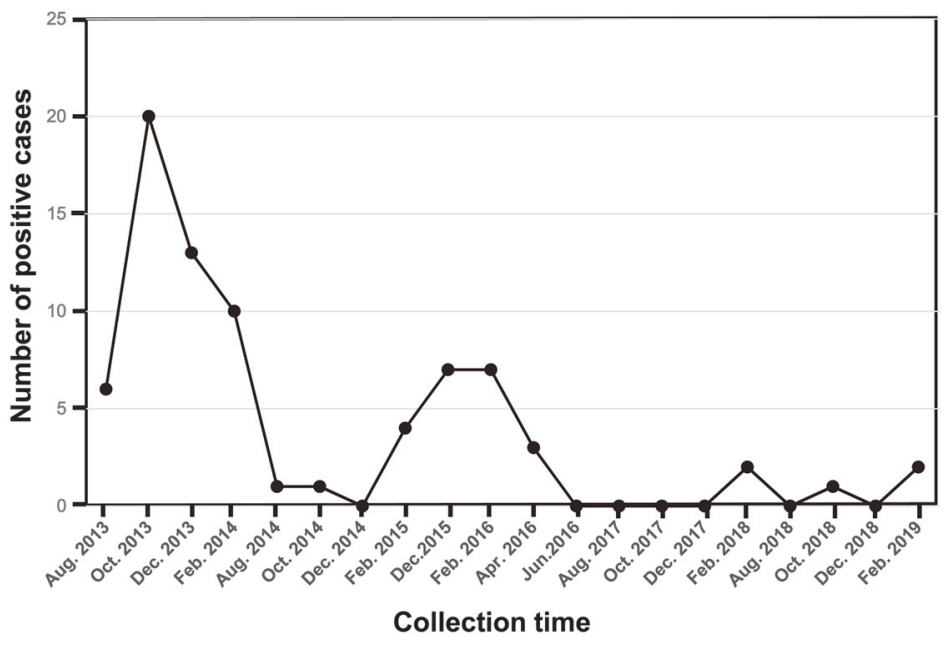

Fig. 1. Total positive incidence cases of noxious bacteria surveillance in this study during the monitoring period.

sampling period, individual targeted noxious bacteria in water samples exhibited seasonal patterns in their occurrence that were different from the indicator bacteria levels in the water samples. The occurrence of noxious bacteria in the samples was higher during the colder months (October, December, and February) than the warmer ones. However, after April 2016, the occurrences of noxious bacteria in the water samples dramatically decreased to $10.39 \%$. This can be attributed to the authorities' effort, such as sewage system management, to improve the water quality. Detection of TC, FC and E. coli in the water samples could not predict the total noxious bacteria presence.

Table 5. Positive incidence cases of each noxious bacterium at the five-water sample collecting sites during the monitoring period in this study.

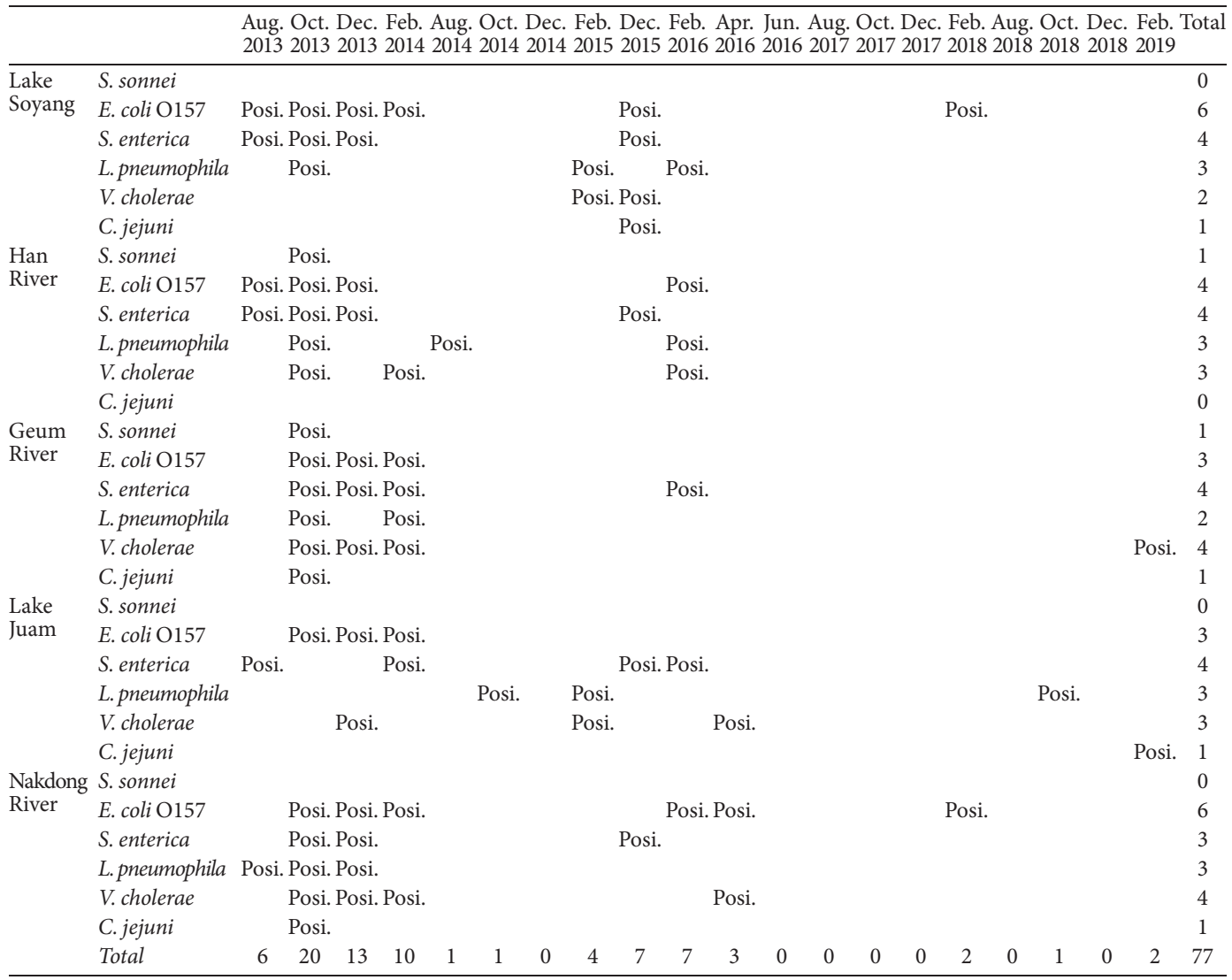




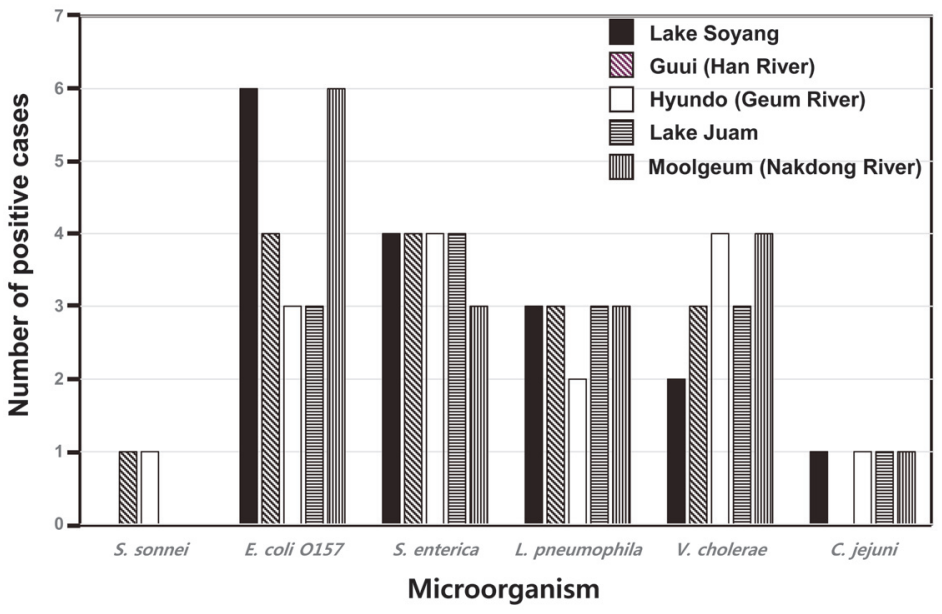

Fig. 2. Positive incidence cases of each noxious bacterium at each collecting site.

Statistical Analysis of Correlation between Indicator Bacteria and the Tested Noxious Bacteria

We performed correlation tests between the monitored six noxious bacteria and the tested three indicator bacteria (TC, FC, E. coli) using permutation technique [33]. Testing results are summarized in Table 6. Only between $S$. enterica and TC has $p$-value less than 0.05 . All the other relationships were not able to look at a significant association. Even in the case of the association between S. enterica and TC, when their $p$-value were adjusted by the Bonferroni calibration, it did not produce any significant results. After Bonferroni adjustment, all the combinations show $p$-values larger than 0.05 . Thus, we concluded that the current results show no statistically significant association in any combination.

\section{Discussion}

The worldwide burden of infectious waterborne disease is considerable, and the bacterial pathogens are strongly resistant in the water environment and to most disinfectants. Some bacterial agents such as $S$. sonnei, C. jejuni and E. coli $\mathrm{O} 157$ can contaminate pristine waters through wildlife and human activities. In addition, climate variables such as precipitation, temperature that have changed significantly as a result of global climate change are major driving forces of food- and waterborne diseases and alter the exposure pathways. These determinants could influence the fate and transport of pathogens, as well as their stability, reproduction rates, and viability in the environment. Therefore, sophisticated and consistent surveillance systems and means should be put in place to monitor the targeted pathogen candidates for serious waterborne diseases.

Some of the noxious bacteria exhibited spatial and seasonal patterns at the collecting sites in this study. The presence of $C$. jejuni in samples from four of the targeted sampling collection sites (except the Guui region of Han River) indicates that positive cases are in fall and winter (October, December and February) but not in spring and summer seasons (August, April, and June), which coincides with previously reported studies [34, 35]. In addition,

Table 6. A statistical association between the monitored noxious bacteria and the tested indicator bacteria.

\begin{tabular}{|c|c|c|c|}
\hline Noxious bacteria & Indicator bacteria & $p$-value & Bonferroni-adjusted $p$-value \\
\hline \multirow[t]{3}{*}{ S. sonnei } & TC & 0.148 & 1 \\
\hline & $\mathrm{FC}$ & 0.304 & 1 \\
\hline & E. coli & 0.38 & 1 \\
\hline \multirow[t]{3}{*}{ E. coli 0157} & TC & 0.268 & 1 \\
\hline & FC & 0.065 & 1 \\
\hline & E. coli & 0.905 & 1 \\
\hline \multirow[t]{3}{*}{ S. enterica } & $\mathrm{TC}$ & 0.014 & 0.252 \\
\hline & FC & 0.262 & 1 \\
\hline & E. coli & 0.28 & 1 \\
\hline \multirow[t]{3}{*}{ L. pneumophila } & TC & 0.326 & 1 \\
\hline & FC & 0.806 & 1 \\
\hline & E. coli & 0.327 & 1 \\
\hline \multirow[t]{3}{*}{ V. cholerae } & TC & 0.54 & 1 \\
\hline & FC & 0.102 & 1 \\
\hline & E. coli & 0.97 & 1 \\
\hline \multirow[t]{3}{*}{ C. jejuni } & TC & 0.876 & 1 \\
\hline & FC & 0.204 & 1 \\
\hline & E. coli & 0.264 & 1 \\
\hline
\end{tabular}


the positive cases for L. pneumophila are in winter except for one in August 2013 at the Moolgeum region site. In the case of $S$. sonnei, there were only two positive cases of samples from the Guui region and the Hyundo region in October 2013 were not linked to seasonality. Similarly, the indicator bacteria TC, FC and E. coli were not consistently and significantly correlated with the detection of the targeted noxious bacteria (Table 6). These data indicate that indicator bacteria and physiochemical parameters used in this study are not potential candidates for predicting the presence of typical noxious bacteria such as S. sonnei, E. coli O157, S. enterica spp., L. pneumophila, C. jejuni, and $V$. cholerae in the surface water at the five targeted surface water sampling locations including the Guui region, the Moolgeum region, the Hyundo region, Lake Soyang and Lake Juam.

According to the results of the monitoring in this study, the occurrences of noxious bacteria in water samples were dramatically decreased after April 2016. Although it is difficult to elucidate the specific cause, this could be attributed to the authorities' effort, such as sewerage system management and social good-informed cognition, to improve the water quality. Korea achieved $92.1 \%$ penetration rate of sewage into the advanced countries through the first National Sewage Comprehensive Plan (NSCP) (2007-2015) through continuous expansion of sewage treatment facilities and sewage systems, improved sewage maintenance, enhancement of sewerage and sewerage management, establishment of water resource circulation utilization systems, and improved sewage treatment technology and sewage sludge treatment [36].

This study has a critical limitation. First of all, in some years during the study, the collection of surface water samples has limitations that have not been carried out as originally planned and thus we were not able to proceed with consistent sample collection and monitoring during the summer season. In addition, since this study was only based on the genetic analysis using PCR methods, we were not able to determine the infectivity and pathogenesis despite the positive detection. Nevertheless, this study was designed and practiced at these specific sites as a project of the National Institute of Environmental Research funded by the Ministry of Environment of the Republic of Korea. In fact, despite the growing interest in monitoring noxious microorganisms, it is difficult to find a case of research on their distribution and monitoring related to climate change at Korea or abroad. The Ministry of Environment of the Republic of Korea recognized the need for this research to provide public health security and secure drinking water stability because of water temperature rise, flooding, drought and heat waves due to climate change increase the prevalence of noxious microbes. The Ministry of Environment had set a Priority Management List (PML) of 20 noxious microbes in groups including TC bacteria, FC bacteria, pathogenic E. coli, enterococci, fecal Streptococci, Pseudomonas as concerns about unregulated waterborne microbes increase.

In conclusion, it was not possible to determine the infectivity and pathogenicity on the six noxious bacteria examined in this study, and it was difficult to precisely identify any noticeable seasonal or regional effects. However, the fact that they were detected in the five Korea's representative water environments comprising lakes, rivers, and drinking water collecting sites make it necessary to establish the chemical and biological analysis for noxious bacteria and sophisticated management systems in response to climate change. Thus, relying on predictive models and monitoring for timely warning can protect the health of the public.

\section{Acknowledgments}

This work was supported by a grant from the National Institute of Environmental Research (NIER-SP2018309, TSK, OJR, and SSL) funded by the Ministry of Environment (MOE) of the Republic of Korea.

\section{Conflict of Interests}

The authors have no financial conflicts of interest to declare.

\section{References}

1. Kovats S, Haines A. 1995. The potential health impacts of climate change: an overview. Med. War. 11: 168-178.

2. McMichael AJ, Woodruff RE, Hales S. 2006. Climate change and human health: present and future risks. Lancet 367: 859-869.

3. Min S-K, Zhang X, Zwiers F, Shiogama H, Tung Y-S, Wehner M. 2013. Multimodel detection and attribution of extreme temperature changes. J. Climate 26: 7430 .

4. Chung Y-S, Yoon M-B, Kim H-S. 2004. On climate variations and changes observed in South Korea. Climate Change 66: 151-161.

5. Rogers DJ, Suk JE, Semenza JC. 2013. Using global maps to predict the risk of dengue in Europe. Acta Trop. 129: 1-14.

6. Anderson M, Sansoneti PJ, Marteyn S. 2016. Shigella diversity and changing landscape: insights for the twenty-first century. Front. Cell. Infect. Microbiol. 6: 45.

7. Centers for Disease Control and Prevention. 2017. CDC Yellow book 2018: Health information for international travel. New York: Oxford University Press.

8. European Center for Disease Prevention and Control. Annual Epidemiological Report 2016 - Shigellaosis [Internet], [Cited 2018 Feb. 16], Stockholm: ECDC; 2016. Available from: https://ecdc.europa.eu/sites/portal/files/documents/Shigellosis-annualepidemiological-report-for 2014_0.pdf. Accessed Mar. 20, 2020.

9. Fratamico P, Smith J. 2006. Escherichia coli infections. In: Riemann H, Cliver D, editors. Food borne infections and intoxications. pp. 3. Elsevier science, New York.

10. Andino A, Hanning I. 2015. Salmonella enterica: survival, colonization, and virulence differences among serovar. ScientificWorldJournal 2015: 520179.

11. Lamas A, Miranda JM, Regal P, Vázquez B, Franco CM, Cepeda A. 2018. A comprehensive review of non-enterica subspecies of Salmonella enterica. Microbiol. Res. 206: 60-73.

12. Grimont PA, Weill FX. 2007. Antigenic Formulae of the Salmonella Serovars, WHO Collaborating Centers for Reference and research on Salmonella, Institute Pasteur, Paris, France.

13. Chahin A, Opal SM. 2017. Severe Pneumonia caused by Legionella pneumophila: differential diagnosis and therapeutic considerations. Infect. Dis. Clin. North Am. 31: 111-121. 
14. Qin J, Lupo ZQ. 2017. Legionella and Coxiella effectors: strength in diversity and activity. Nat. Rev. Microbiol. 15: 591-605.

15. Sabria M, Yu VL. 2002. Hospital-acquired legionellosis: solutions for a preventable infection. Lancet Infect. Dis. 2: 368-373.

16. van der Stel A-X, Wönsten MMSM. 2019. Regulation of respiratory pathways in Campylobacterota: a review. Front. Microbiol. 10: 1719.

17. Ramees TP, Dhama K, Karthik K, Rathore RS, Kumar A, Saminathan M, et al. 2017. Arcobacter: an emerging food-borne zoonotic pathogen, its public health concerns and advances in diagnosis and control - a comprehensive review. Vet. Q. 37: 136-161.

18. World Health Organization. 2000. World Health Organization 2000; Annual report on campylobacteriosis. Copenhagen, Denmark; World Health Organization.

19. Konkel ME, Monteville MR, Rivera-Amill V, Jones LA. 2001. The pathogenesis of Campylobacter jejuni-mediated enteritis. Curr. Issues Intest. Microbiol. 2: 55-71.

20. Reidl J, Klose KE. 2002. Vibrio cholera and cholera: out of the water and into the host. FEMS Microbiol. Rev. 26: 25-136.

21. Clemens JD, Nair GB, Ahmed T, Qadri F, Holmgren J. 2017. Cholera. Lancet 390: 1539-1549.

22. Climate Institute, Water. Available at: https://www.climate.org/topics/ water.html. Accessed Aug. 17, 2019.

23. Highsmith AK, Abshire RL. 1975. Evaluation of a most probable number technique for the enumeration of Psudomonas aeruginosa. Appl. Microbiol. 30: 596-601.

24. Rice EW, Baird RB, Eaton AD, Clesceri LS. 2012. Standard Methods for the Examination of Water and Wastewater, $21^{\text {st }}$ Ed. American Water Works Association, Denver, CO, USA

25. Walter WG. 1998. APHA standard methods for the examination of water and wastewater. Health Lab. Sci. 4: 137.

26. Young JC, Clesceri LS, Kamhawy SM. 2005. Changes in the biochemical oxygen demand procedure in the $21^{\text {st }}$ Ed. of Standard Methods for the Examination of Water and Wastewater. Water Environ. Res. 77: 404-410.

27. Jin YJ, Park YK, Cho MS, Lee ES, Park DS. 2018. New insight and matrics to understand the ontogeny and succession of Lactobacillus plantarum subsp. plantarum and Lactobacillus plantarum subsp. argentoratensis. Sci. Rep. 8: 6029.

28. World Health Organization. 2017. Guidelines for Drinking-water Quality, $4^{\text {th }}$ Ed. World Health Organization, Geneva, Switzerland.

29. Canter L 1997. Nitrates in Groundwater, CRC Press, Boca Raton, Fla, USA.

30. Sidhu JPS, Toze SG. 2009. Human pathogens and their indicators in biosolids; A literature review. Environ. Int. 35: 187-201.

31. Pennsylvania Department of Environmental Protection (PA DEP), (2019), Pa. Code $\$ 109.301$. General monitoring requirements, Online at: http://www.pacodeandbulletin.gov/Display/pacode?file=/secure/pacode/data/025/chapter109/s109.301.html\&searchunitkeywords $=$ water\%2Cquality\&origQuery=water\%20quality\&operator=OR\&title=null. Accessed Jan. 17, 2020

32. Kalkan S, Altug G. 2015. Bio-indicator bacteria \& environmental variables of the coastal zones: the example of the Güllük Bay, Aegean Sea, Turkey. Mar. Pollut. Bull. 95: 380-384.

33. Corain L, Salmaso L. 2004. Multivariate and multistrata nonparametric tests: the NPC method. J. Mod. Appl. Stat. Methods 3: 443461.

34. Obiri-Danso K, Jones K. 1999. Distribution and seasonality of microbial indicators and thermophilic Campylobacters in two freshwater bathing sites on the River Lune in north-west England. J. Appl. Microbiol. 87: 822-832.

35. Semenza JC, Herbst S, Rechenburg A, Suk JE, Höser C, Schreiber C, et al. 2012. Climate change impact assessment of food- and waterborne disease. Crit. Rev. Environ. Sci. Technol. 42: 857-890.

36. Kim HJ, You JY, Park CJ. 2017. Review of sewage and sewage sludge treatment in Korea. Int. Proc. Chem. Biol. Environ. Eng. 101: 67- 